\title{
Imperiled Species and Communities Threatened by Invasive Species
}

\section{Introduction}

The impacts of invasive species on our economy and ecosystems are now a fact of life in the United States. Extensive studies have shown that the unchecked invasion of non-native species is causing billions of dollars worth of damage to U.S. agriculture, forestry, and human and wildlife health, as well as threatening the vital functions that natural ecosystems support. A less well known fact is that invasive species threaten one of our most precious natural resources-imperiled species and communities.

\section{What Are Imperiled Species?}

"Imperiled species" is a general term used to identify species and populations of animals and plants that are in decline and may be in danger of extinction. Many imperiled species have legal protection under Federal laws such as the Endangered Species Act or under State statutes. Many species, however, are not being protected because of a lack of knowledge about their status and the environmental factors that may threaten their future. As the principal research agency for the U.S. Department of the Interior, the U.S. Geological Survey (USGS) is conducting research to fill the gaps in our understanding so that imperiled species can be better managed and conserved.

\section{How Do Invasive Species Affect Imperiled Species?}

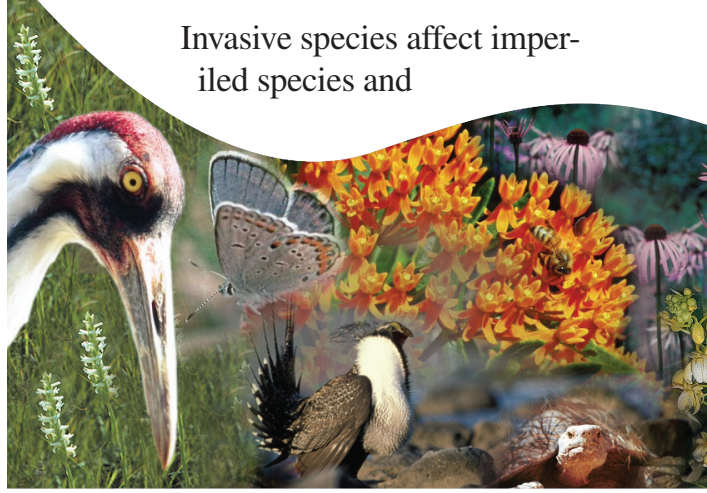

Figure 1. Brown tree snake. The "cat eyes" appearance is a distinguishing characteristic. Photographs by Gordon Rodda, U.S. Geological Survey; from http://www.forestryimages.org.

damage natural and human ecosystems in a number of ways. Examples include the following:

- Predation. Shortly after World War II, the brown tree snake (fig. 1) was accidentally introduced from its native range in the South Pacific into Guam, probably as a stowaway in ship cargo. Like many island ecosystems, Guam is particularly vulnerable to invasive predators because it has few native predators. With abundant prey and no significant predators to control them, brown tree snakes multiplied unchecked, reaching densities of up to 13,000 per square mile. These mildly venomous predators have virtually wiped out the native forest animals. Ten species of birds, some found nowhere else, have disappeared from the island. Brown tree snakes have also caused thousands of power outages by crawling onto electric lines, killed domestic poultry and pets, and invaded human habitats. There is the very serious risk that brown tree snakes may be introduced accidentally onto other Pacific islands as passive stowaways in ship and air traffic from Guam. USGS researchers are actively developing methods to control this threat to native species and providing guidance on how to

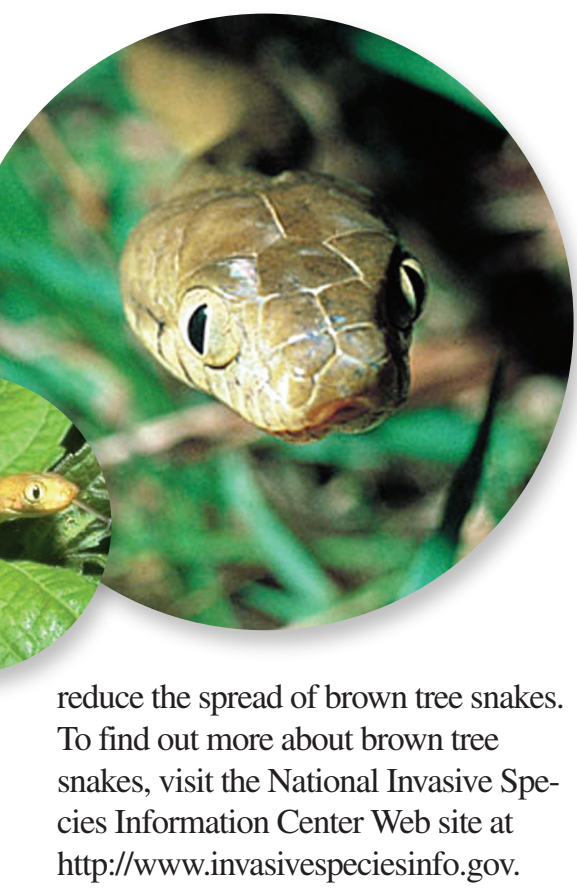

- Altered Ecosystems. Invasive species can affect entire ecosystems. In recent years, the Great Basin and High Plains of the Western United States have been transformed by fire. Fire is a natural component of these ecosystems, but the frequency and timing of fires have increased sharply due to the introduction and spread of invasive non-native grasses. Introduced species such as buffel grass, red brome, and crested wheatgrass complete their life cycle early in the fire season, but their dried stalks are persistent and can add to fuel loads for 2 to 3 years after the seeds have dropped (see http://www.usgs.gov/ invasive_species/plw/grassfire.html). Native plant species such as sagebrush cannot survive frequent and intensive fires (fig. 2), and as a result, these keystone species are disappearing from the landscape. As native 


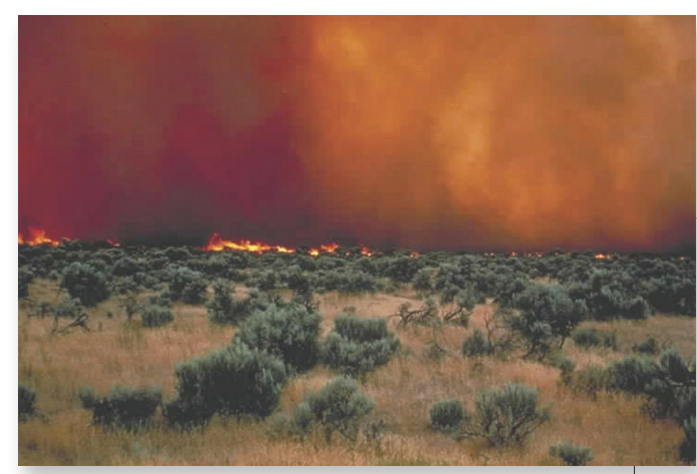

habitat declines, so do the populations of important native animal species, such as sage grouse. Teams of USGS scientists are conducting studies to track and control invasive plants, as well as studying sage grouse and other species adversely affected by invasive species. The scientists are examining how energy development, grazing, and other human activities can be modified to reduce multiple impacts on imperiled species. To find out more about the impact of non-native grasses, visit the USGS GIS database Sage Grouse and Shrubsteppe Management in the Intermountain West (at http://sagemap.wr.usgs.gov).

- Competition. Most invasive species are generalists that live in a variety of habitats, including habitats disturbed by human activities. Zebra mussels were first discovered in the Great Lakes in 1988 and have since spread throughout the Great Lakes and the Mississippi Valley and into the Northeastern United States. Zebra mussels have had severe impacts on native mussel species already at risk of extinction due to the effects of pollution, dams, and other factors. These invaders compete directly with native species by removing food sources, occupying otherwise available space, and anchoring themselves by the thousands to native hosts (fig. 3), making it impossible for the hosts to function. As many as 10,000

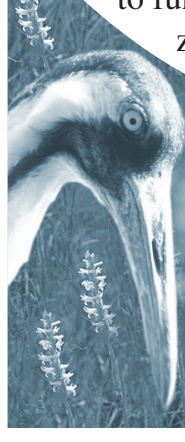
zebra mussels have

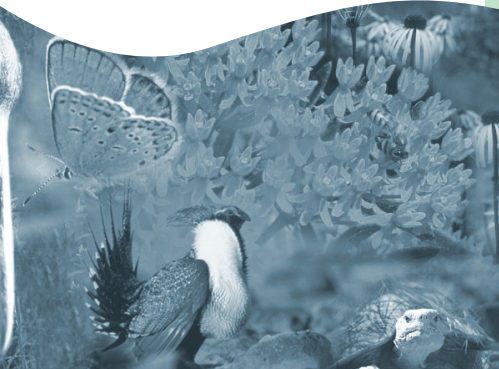

Figure 2. Unlike native sagegrass, invasive non-native grasses can withstand frequent and intense wildfires. Photograph courtesy of the U.S. Geological Survey.

attached to a single native mussel (see http://cars.er.usgs.gov/ Nonindigenous_Species/ Zebra_mussel_FAQs/ zebra_mussel_faqs.html). Zebra mussels tolerate a wide range of conditions and reproduce extremely rapidly; they can alter species composition and water chemistry of entire systems of lakes and rivers. USGS biologists and hydrologists have identified pathways and ways to slow their spread into new habitats; they have also identified locations where imperiled mussel species can find refuge from zebra mussels and maintain populations. Finally, they are discovering ways to rear endangered mussels in hatcheries and reintroduce them into habitats free of zebra mussels. To find out more about zebra mussels and other aquatic invaders, check out the USGS Nonindigenous

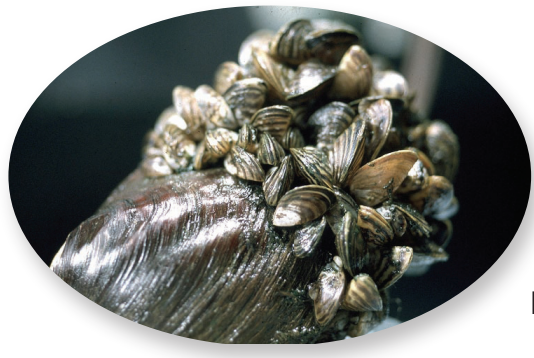

Figure 3. Zebra mussels anchor themselves by the thousands to native bivalve hosts. Photograph by Randy Westbrooks, U.S. Geological Survey; from http://www.forestryimages.org.
Aquatic Species (NAS) database (at http://nas.er.usgs.gov).

\section{Research for the Future}

USGS researchers are creating knowledge and tools to prevent or control the proliferation of invasive species and to reduce their impacts on our natural heritage. The USGS is working across science disciplines and with other partners to bring innovative approaches to resource managers, policymakers, and the public. For example, the USGS is using advanced technologies to monitor the distribution and abundance of both invasive species and native species and communities. These technologies are important tools in focusing resources to preclude, control, or eradicate invasive species in sensitive native habitats. Sophisticated computer models are being applied to forecast which native species and populations may be at greatest risk. These and other research tools are being applied by Government agencies and private citizens to turn the tide of invasive species in the United States and to protect the natural resources vital to our future.

\section{By Rachel C. Muir}

Visit the USGS home page at http://www.usgs.gov or contact:

Rachel Muir

E-mail: rachel_muir@usgs.gov

Telephone: 703-648-5114

U.S. Geological Survey

301 National Center

12201 Sunrise Valley Drive

Reston, VA 20192

\section{Sharon Gross \\ E-mail: sgross@usgs.gov Telephone: 703-648-4076}

About LINKS Fact Sheets. The mission of the U.S. Geological Survey is to provide quality science information in the disciplines of biology, geology, geography, and hydrology. Its diverse array of experience and expertise enables the USGS to conduct interdisciplinary science in support of its mission goals. LINKS Fact Sheets present information on how USGS programs Fact Sheets present information on how USGS program
work together to address the complex science
needs of the Nation.

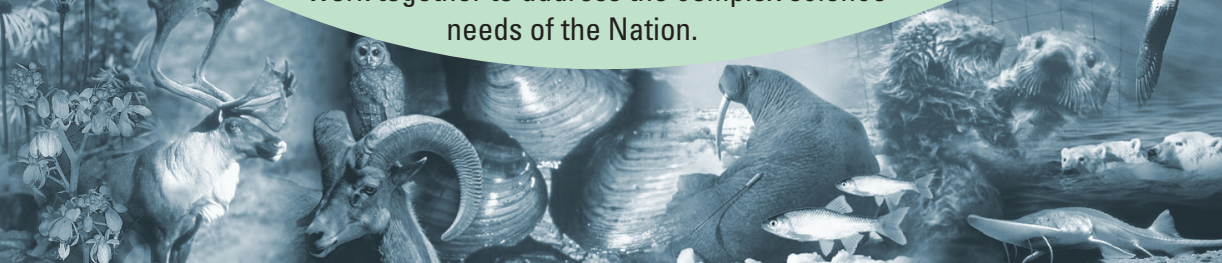

